International Journal of Management Science and Business Administration

Volume 5, Issue 6, September 2019, Pages 29 - 37

DOI: $10.18775 /$ ijmsba.1849-5664-5419.2014.56.1004

URL: http://dx.doi.org/10.18775/ijmsba.1849-5664-5419.2014.56.1004

\title{
Interfirm Collaboration Cluster as Source of Competitiveness to Enhance Performance
}

\author{
${ }^{1}$ Mochamad Taufiq, ${ }^{2}$ Elia Ardyan, ${ }^{3}$ Naili Farida \\ ${ }^{1,2,3}$ Doctoral Program of Social Sciences, Faculty of Social and Political Sciences, \\ Diponegoro University, Semarang, Indonesia
}

\begin{abstract}
Cluster is one of the competitive advantages for small business in Indonesia. This study examines the role of interfirm collaboration clusters and product competitiveness on small business performance. The sample used in this study were 317 owners or managers of furniture business in Central Java, Indonesia. The analysis used is structural equation modeling (SEM). The results of this study indicate the important role of interfirm collaboration clusters on product innovation and Small business performance. Other research results indicate that customer centricity has an effect on product innovation. This research also contributes both theoretically and managerially.
\end{abstract}

Keywords: Interfirm collaboration cluster, Customer centricity, Product innovation and Small business performance

\section{Introduction}

The cluster industry is a group of companies which are geographically in the same industry (Krugman, 1991). Currently the industrial cluster has been regarded as one of the most important channels toward open innovation and economic excellence (Zhao et al., 2010). The development of industrial integration clusters is the characteristic of regional development and supports the synergy between companies in achieving long-term collaborative goals (Lai \& Woodside, 2015). Many small businesses are difficult to collaborate. Sabath and Fontanella (2002) explain that collaboration is very difficult to be implemented. Inter-enterprise collaboration becomes difficult to be implemented when there has different market segment (Barratt \& Oliveira, 2001), difficulty in trusting partners, lacking collaborative experience (Barratt \& Oliveira, 2001), difficulties in sharing of benefits and risks (Stank et al., 2001). Collaboration is not merely developing closer relationships, but must be able to integrate all existing functions within the company (Ireland \& Bruce, 2000) and corporate strategy (Barratt \& Oliveira, 2001) with partner companies. Therefore, companies that are able to collaborate with other companies have a very superior competence.

The gap in this study is the impact of agglomeration in the cluster. Companies in industry tend to cluster in small areas because of the positive externalities underlying the agglomeration economy (Hong, 2011). Agglomeration economies exist because there is scale of economies in economic activity that occur close to each other (Holcombe, 2012). Some literature describes the benefits of agglomeration. Agglomeration effects on the search costs (Stahl, 1982), economic growth (Berliant \& Wang, 2005), maintains excellence (Holcombe, 2012), makes manufacturing industry become smaller, more specialist, and more concentrated in a particular field (Crawley \& Hill, 2011). Even according to the results of research that was done by Marco-Lajara et al. (2014), shows that agglomeration impacts on the profitability of the company (hotelier industry). In Indonesia, agglomeration in furniture clusters is very dangerous (Ardyan, 2016). Ardyan (2016) and Su et al. (2017) explained that the agglomeration system makes many Small business compete through low prices. Many Small business cannot afford to do the economic scale. This is what makes the profit decreases and also affects to the overall performance decline. Mare and Graham (2013) explain that the increase in agglomeration makes the company's performance decline (mining, agriculture and fishery sector).

To solve the problem, some researchers explain some of the factors that make agglomeration successful in the cluster system, by selecting to the appropriate locations (Marco-Lajara et al., 2014; Wiese, 2017) and able to do the economic scale. It is rarely found agglomeration research focus on collaboration and product competitiveness. In this research, 
Small business in certain clusters must have strong collaboration among Small business. In addition to focus on improving collaboration within clusters, Small business should develop competitive products. These two capabilities affect the performance of Small business. Therefore, the purpose of this study is to examine the role of Small business performance.

\section{Literature Review}

\section{Resources Advantages Theory and Interfirm-Collaborating Clusters}

Resources advantages theory defines a resource as a tangible or intangible entity owned by a company, which can generate both effective and efficient market supply that gives value to its market segment (Hunt, 1997). Resources are divided into several forms, they are: finance (access to capital markets), physical (buildings, raw materials, equipment), laws (trademarks and licenses), organizational (competence, control / strength, policy and culture) Information (information about consumers, competitors, and technology), relation (relationships with competitors, suppliers, employees, and consumers). Collaboration between companies relates to the company's relational resources. Allred et al. (2011) explained that the ability to build collaboration is one of the competitive advantages that must be owned by the company. Sigalas et al. (2013) defines competitive advantage is as a company's ability to exploit market opportunities and competitor threats where capabilities are above the industry average. Day and Wensley (1988) explain that a firm's superiority in skills and / or resources makes it possible to develop a position of excellence over its competitors. Various approaches explain about the basis of collaboration. Alliance networks tend to be very crowded. Some groups of companies will have more connections that connect them to each other than other companies on the network (Schilling \& Phelps, 2007). Clusters are a group of companies from the same or related industries that are geographically close to each other (Harrison et al., 1996). Inter-company collaboration can be a source of competitive advantage for a company (Lai \& Woodside, 2015). Collaborative companies can innovate new products faster, have workers acquire new skills and gain more capital investment at a lower cost (Brink, 2017).

\section{Customer Centricity}

Customers are regarded as the center where business always strives to create value for its customers (Johnson et al., 2008). Customer centricity or customer focus has been described in different ways in the literature and is often associated with concepts such as market orientation, marketing concepts, and " first customers " (Nwokah \& Maclayton, 2006). Customer centricity is defined as the management hypothesis of what consumers want, how they want it, and how companies can organize in order to fulfill it to gain profit. Frankenberger et al. (2013) concludes that customer centricity is divided into 3 dimensions: (1) customer-oriented values and beliefs, (2) organizational structure using a special unit to deal with customers, (3) organizational focus is finding and satisfying customer needs.

Many researchers explain that focusing on consumers is the most fundamental aspect in companies' culture (Desphande et al., 1993). Customer focus is critical to the profitability of the business, the necessary competitive advantage, and the hallmark of successful business (Diamantopoulos \& Hart, 1993; Narver \& Slater, 1990; Nwokah \& Maclayton, 2006). Orientation to customers and the market will increase the profitability of the company (Narver \& Slater, 1990)). Some researchers explain that focusing on customers will enable the company to improve its performance (Nwokah, 2009; Nwokah \& Maclayton, 2006).

\section{Product Competitiveness}

In general the term of competitiveness means the ability and offer of an organization related to a competitor (Bowman, 1992). Competitiveness is the advantage position of the company (Feurer \& Chaharbaghi, 1994) compared to its competitors (Moon \& Perry, 1995). In the context of products, the competitiveness of a company's products as a level where the company's product offerings are perceived to have superior fitness to be used, free of deficiencies, and compliance with requirements compared to competing companies (Luo, 2010). Product competitiveness refers to superior product quality which is felt relative to competitors (Luo, 2010). The product has competitiveness when the price is cheap and different from its competitors (Moon \& Perry, 1995). Akroush (2012) explains that product competitiveness goes into product quality and speed to market.

\section{Small business Performance}

Small business performance is a complex and multidimensional concept (Scase \& Goffee, 1984). This is shaped by the actions and abilities of the owners of small busines, and is very dependent on their perception of the performance and direction of the business (Morrison \& Teixeira, 2004). Company performance is a common construct used to measure the impact of corporate strategy (Beard \& Dess, 1981). Company strategy is always directed to good performance in 
the form of marketing performance and financial performance (Ferdinand, 2000). Market performance is a concept to measure the market performance of a product. As a mirror of the success in the business competition, every company has an interest to know the market achievements of its products.

\section{Hypothesis}

\section{Influence Interfirm Collaboration Cluster on Product Competitiveness}

One concept that strongly supports customer centricity is the collaboration between consumers and companies. Joint creation is a shared participation between consumers and producers to create values in the market (Swass, 2010). Incorporating consumers in joint creation is a very important strategy to satisfy the demand for product personalization and to create competitive combat (Zhang \& Chen, 2008). Joint value creation focuses on how companies motivate their customers to gather designing products, services, and do the innovation together (Lehrer et al., 2012). Co-creation is about creating together and individual evolutions through interaction (Prahalad \& Ramaswamy, 2004). Co-creation is not about customization of goods and services, one on one marketing, or customer experience across every company's sector. Vieira (2009) believes that relationship quality is seen as a key factor of competitive advantage. Cluster makes the company more innovative (Harrison, 1994) so as to create a variety of creative products. The clusters and mechanisms in them greatly influence innovations (Bell, 2005).

H1: Interfirm collaboration cluster positively affects product competitiveness

\section{Influence of Interfirm Collaboration Cluster on Small Business Performance}

The understanding that a superior relationship with consumers impacts financial performance is part of the development of marketing practice and theory (Morgan \& Hunt, 1994). In the study of marketing studies, the purpose of building relationships is to create long-term profit and performance (Hultman \& Shaw, 2003; Palmatier, 2008; Palmatier et al., 2008; Ravald \& Gronroos, 1996; Tse et al., 2004). Wang et al. (2015) said that collaboration between Small business in the cluster is expected to improve the performance of each SME. Collaboration enables Small business to transfer knowledge, experience, technology and other resources to create value to their customers. Value creation is expected to improve the competitiveness of Small business and will impact on the performance of Small business.

H2: Interfirm collaboration cluster positively affects the performance of Small business

\section{The Influence of Customer Centricity in Product Competitiveness}

In the marketing literature, being close to the customer can provide the benefit of having a competitive advantage (Hulland et al., 2007). Strong customer orientation is predicted enable to increase existing customer confidence, future market focus for example, able to predict market segment and sensitivity to new trend of technology (Hulland et al., 2007). Warning for emerging needs, new customer segments and technology trends in the market, companies with a future market as the focus tend to have a proactive attitude and not only a reactive attitude for business. Using kinds of tactics (such as hiring futurists and launching low cost experimental products), companies with future market focuses that are able to anticipate the future and develop their organizational vision in the future (Marques \& Ferreira, 2009).

H3: Customer centricity positively affects product competitiveness

\section{Influence of Product Competitiveness on SME Performance}

Speed-based competition becomes very important in business (Wang \& Wang, 2012). In recent years, many companies are rapidly issuing new products, services and quick processes. The phenomenon in Indonesia says that consumers are looking forward to the new product. Tidd et al. (2005)explains that the companies which capable to respond faster in launching new products with the least expensive time and cost, increase the performance of the company. Every company that has a rapid response to the fulfillment of consumer needs will certainly improve the company performance (Homburg et al., 2007; Jaworski \& Kohli, 1993; Wei et al., 2014).

H4: Product competitiveness positively affects the performance of Small business

The empirical research model developed in this study is shown in Figure 1. 


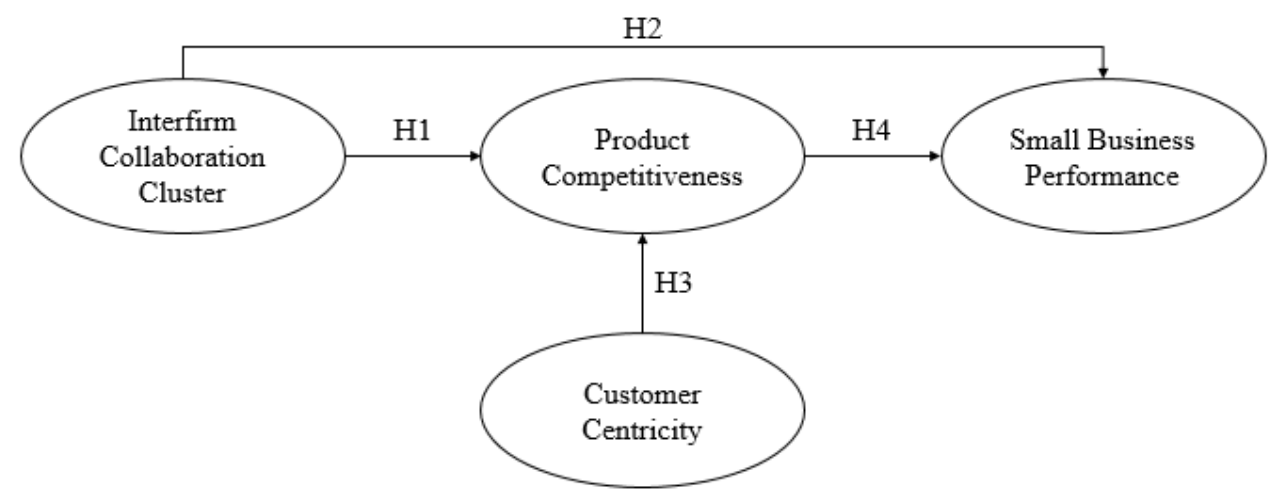

Figure 1: Empirical Research Model

\section{Methodology}

\section{Respondents}

This study examines the SME Cluster of Furniture in the Region of Central Java. There are several clusters in several cities in Central Java, those are Furniture clusters in the city of Jepara, Solo, Sragen, Klaten, and Sukoharjo. Respondents of this study are the owners of Small business or SME managers. Questionnaires were distributed to 500 respondents. But, data returned and can be used for further analysis are 317 respondents (response rate 63.45).

\section{Measurement}

\section{Interfirm Collaboration Cluster}

Interfirm collaboration cluster indicator is adopted by Lai and Woodside (2015), they are: knowledge sharing, strategic collaboration, business concept and mutual trust. The interfirm collaboration cluster indicator is measured using a scale of 1 to 7 . The $1^{\text {st }}$ scale describes the highly disagree answer and the $7^{\text {th }}$ scale describes the strongly agreed answer.

\section{Customer centricity}

Frankenberger et al. (2013) concludes that customer centricity is divided into 3 dimensions: (1) customer-oriented values and beliefs, (2) organizational structure using a special unit to deal with customers, (3) organizational focus is finding and satisfying customer needs. The customer centricity indicator is measured using a scale of 1 to 7 . The $1^{\text {st }}$ scale describes the highly disagree answer and the $7^{\text {th }}$ scale describes the strongly agreed answer.

\section{Product Competitiveness}

The competitiveness product indicator is adopted from Feurer and Chaharbaghi (1994) and Akroush (2012) they are new product speed, new product quality, and new product development flexibility. The product competitiveness indicator is measured using a scale of 1 to 7 . The $1^{\text {st }}$ scale describes the highly disagree answer and the $7^{\text {th }}$ scale describes the strongly agreed answer.

\section{Small business Performance}

Small business performance indicators is adopted from Ardyan (2016) and Morgan (2012) they are profit growth, customer growth, market share growth, and sales growth. The Small business performance indicator is measured using a scale of 1 to 7 . The $1^{\text {st }}$ scale describes the highly disagree answer and the $7^{\text {th }}$ scale describes the strongly agreed answer.

\section{Results}

\section{Measurement Model}

In the measurement model, the first thing to test is validity and reliability. Validity test using loading factor and average variance extracted (AVE). Instruments are said to be valid if factor loading and AVE values are above 0.5 (Hair et al., 2010). In table 1 it is clear that both the loading and the AVE values are above 0.5, so that all items in the instrument are valid. Reliability testing uses composite reliability (CR). CR value must be above 0.6. Table 1 explains that the CR value is above 0.6 (Hair et al., 2010), so it can be concluded that the instrument is reliable. 
Mochamad Taufiq, Elia Ardyan, Naili Farida

Interfirm Collaboration Cluster as Source of Competitiveness to Enhance Performance

Table 1. Validity and Reliability Testing

\begin{tabular}{|l|c|}
\hline Variabel \& Indicator & Factor Loading \\
\hline Interfirm Collaboration Cluster (AVE=0.728; CR=0.915) & 0.878 \\
Knowledge Sharing & 0.866 \\
Strategic Collaboration & 0.848 \\
Business Concept & 0.821 \\
Mutual Trust & \\
\hline Customer Centricity (AVE= 0.608; CR=0.860) & 0.825 \\
Customer-oriented values & 0.866 \\
Customer-oriented beliefs & 0.713 \\
Organizational structure uses a special unit to deal with customers & 0.702 \\
Organizational focus is to find and satisfy the customer needs & 0.790 \\
\hline Product Competitiveness (AVE=0.641; CR=0.842) & 0.819 \\
New product speed & 0.792 \\
New product quality & \\
New product development flexibility & 0.836 \\
\hline Small business Performance (AVE=0.665; CR=0.888) & 0.750 \\
Profit Growth & 0.831 \\
Customer Growth & 0.842 \\
Market Share Growth & \\
Sales Growth & \\
\hline
\end{tabular}

Second, test the goodness of fit. Goodness of fit is a condition where data are fit with the built model. In this study used several indicators of goodness of fit, among others The employed as follows measurements: Chi-Square $=99.233$; $\mathrm{p}=$ 0.139; Goodness of Fit Index $(\mathrm{GFI})=0.960$, Tucker Lewis Index $(\mathrm{TLI})=0.994$, Comparative Fit Index $(\mathrm{CFI})=0.995$ and Root Mean Square Error of Approximation $($ RMSEA) $=0.023$. All indicators of goodness of fit are good, so the model built is fit with the data.

\section{Hypothesis testing}

Table 2 describes hypothesis testing. Of the four proposed hypotheses, all are accepted (H1, H2, H3, and H4).

- Interfirm collaboration cluster positively affects to product competitiveness $(\beta=0,517 ; \alpha<0.001)$. So H1 is accepted.

- Interfirm collaboration clusters have a positive effect on Small business performance $(\beta=0.303 ; \alpha<0.001)$. So H2 is accepted

- Customer centricity positively affects to product competitiveness $(\beta=0.272 ; \alpha<0.001)$. So H3 accepted.

- Product competitiveness has a positive effect on Small business performance $(\beta=0.551 ; \alpha=0.004)$. So H4 is accepted

Table 2: Hypothesis Testing

\begin{tabular}{|c|c|c|}
\hline HYPOTHESIS & RESULT & DESCRIPTION \\
\hline $\begin{array}{lll}\text { H1: } & \text { interfirm collaboration cluster } & \rightarrow \\
\text { product competitiveness } & & \end{array}$ & $\beta=0,517 ; \alpha<0.001$ & H1 accepted \\
\hline $\begin{array}{l}\text { H2: interfirm collaboration cluster } \rightarrow \text { Small } \\
\text { business Performance }\end{array}$ & $\beta=0.303 ; \alpha<0.001$ & H2 accepted \\
\hline H3: $\begin{array}{l}\text { Customer centricity } \rightarrow \text { product } \\
\text { competitiveness }\end{array}$ & $\beta=0.272 ; \alpha<0.001$ & H3 accepted \\
\hline $\begin{array}{l}\text { H4: product competitiveness } \rightarrow \text { Small } \\
\text { business Performance }\end{array}$ & $\beta=0.551 ; \alpha=0.004$ & H4 accepted \\
\hline
\end{tabular}




\section{Discussion and Conclusion}

In this study, product competitiveness is influenced by interfirm collaboration clusters and customer centricity. Product competitiveness means the superiority level of the product, where the product does not have any shortage and able to compete with the competitor's product (Luo, 2010). Products with a high degree of superiority are obtained because of the collaboration between parties within the cluster. Some studies have found that networks built within clusters can improve product innovation performance (Bell, 2005; Zhao et al., 2010). Clusters will be able to increase competition and collaboration that ultimately impact on innovation (Chuluunbaatar et al., 2014). In Indonesia, networks are built within clusters are very powerful. It is not only the network is strong, but also the bonds are built very tightly. Relationships within these networks make trust and commitment workable (Morgan \& Hunt, 1994). Good trust between the parties will make the parties in the cluster will share their knowledge, experiences, and technology. This is what will make the parties in the cluster will create products that are more competitive than competitors outside their clusters. Besides interfirm collaboration clusters, customer centricity is also becoming an important part of improving product competitiveness. Customer centricity enables the company to drive all of its strategies in harmony with its customers' demands (Ross, 2009). Customer centricity will enable the company to provide solutions to its customers (Frankenberger et al., 2013), one of which is by providing superior product as the solutions for its customers.

The study also found that interfirm collaboration cluster and product competitiveness can improve SME's performance. Collaboration systems within the cluster will have an impact on increasing incomes (Campbell-Kelly et al., 2010). Clusters are also capable to promote the economic growth (Scott, 2006). Bek et al. (2013) explains that interfirm collaboration will enable Small business to have high performance and innovative activities. Interfirm collaboration will also have an impact on marketing activities (Felzensztein et al., 2012) as well as marketing performance. Products that compete and innovate will certainly have an impact on the performance of Small business (Ardyan, 2016; Ardyan et al., 2017; Sugiyarti \& Ardyan, 2017).

The theoretical implication in this research is interfirm-collaborating cluster is the excellence of the company's own. Without collaboration, the company will not effectively build, combine, co-ordinate and integrate the skills that the collaborating parties have. This capability will enable the company to produce highly competitive products and will also have an impact on its performance. The managerial implication in this research is that Small business should be able to focus on establishing collaboration between parties within the cluster. Trust must be built so that any collaborating party will dare to share, whether knowledge, experience, or other resources. Besides trust, commitment must be maintained to always collaborate and give benefit to each other. Without commitment the collaboration will not work properly.

\section{Limitations and Future Research}

The limitations of this study do not distinguish between formal, semi-formal or non-formal types of collaboration. In this study, examined some furniture industry clusters in five cities in Central Java. Each city has different cluster characteristics. For future research it is hoped that the researchers distinguish clusters into formal, semi-formal or nonformal types, so that each type can be known as the result of interfirm collaborating cluster.

\section{References}

- Akroush, M. N. (2012). Organizational capabilities and new product performance: The role of new product competitive advantage. Competitiveness review: An International Business Journal, 22(4), 2012. Crossref

- Allred, C. R., Fawcett, S. E., Wallin, C., \& Magnan, G. M. (2011). A dynamic collaboration capability as a source of competitive advantage. Decision Sciences, 42(1), 129-161. Crossref

- Ardyan, E. (2016). Market sensing capability and SMEs performance: The mediating role of product innovativeness success. DLSU Business and Economics Review, 25(2), 1-18. $\underline{\text { Crossref }}$

- Ardyan, E., Nurtantiono, A., Istiyanto, B., \& Rahmawan, G. (2017). Green innovation capability as driver of sustainable competitive advantage and SMEs marketing. International Journal of Civil engineering and Technology, 8(8), 1114-1122.

- Barratt, M., \& Oliveira, A. (2001). Exploring the experiences of collaborative planning: The enablers and inhibitors. International Journal of Physical Distribution \& Logistics Management, 31(2), 266-289. Crossref

- Beard, D. W., \& Dess, G. G. (1981). Corporate-Level Strategy, Business-Level Strategy, and Firm Performance. The Academy of Management Journal, 24(4), 663-688. Crossref 
- Bek, M. A., Bek, N. N., Sheresheva, M. Y., \& Johnston, W. J. (2013). Perspectives of SME innovation clusters development in Russia. Journal of Business \& Industrial Marketing, 28(3), 240-259. Crossref

- Bell, G. G. (2005). Clusters, networks and firm innovativeness. Strategic Management Journal, 26, $287-295$. $\underline{\text { Crossref }}$

- Berliant, M., \& Wang, P. (2005). Dynamic Urban Models: Agglomeration and Growth. In R. Capello \& P. Nijkamp (Eds.), Urban Dynamics and Growth: Advances in Urban Economics (pp. 533-581): Emerald Group Publishing Limited. $\underline{\text { Crossref }}$

- Bowman, C. (1992). Charting Competitive Strategy. In D. Faulkner \& G. Johnson (Eds.), The Challange of Strategic Management. London: Kogan Page.

- Brink, T. (2017). SME routes for innovation collaboration with larger enterprises. Industrial marketing Management, 64, 122-134. Crossref

- Campbell-Kelly, M., Danilevsy, M., Garcia-Swartz, D. D., \& Pederson, S. (2010). Clustering in the creative industries: Insights from the origins of computer software. Industry \& Innovation, 17(3), 309-329. Crossref

- Chuluunbaatar, E., Ottavia, O., Luh, D.-B., \& Kung, S.-F. (2014). The Role of Cluster and Social Capital in Cultural and Creative Industries Development. Procedia-Social and Behavioral Sciences, 109, 552-557. Crossref

- Crawley, A. J., \& Hill, S. (2011). Is industrial agglomeration increasing? New evidence from a small open economy. Journal of Economic Studies, 38(6), 725-740. Crossref

- Day, G. S., \& Wensley, R. (1988). Assessing Advantage: A Framework for Diagnosing Competitive Superiority. Journal of Marketing, 52(April), 1-20. $\underline{\text { Crossref }}$

- Desphande, R., Farley, J. U., \& Webster, F. E. (1993). Corporate culture, customer orientation, and innovative in Japanese firms: a quadrad analysis. Journal of Marketing, 57(Januari), 23-37. Crossref

- Diamantopoulos, A., \& Hart, S. (1993). Linking market orientation and company performance: preliminary evidence of Kohli and Jaworski's framework. Journal of Strategic Marketing, 1, 93-121. Crossref

- Felzensztein, C., Gimmon, E., \& Aqueveque, C. (2012). Clusters or un-clustered industries? Where inter-firm marketing cooperation matters. Journal of Business \& Industrial Marketing, 27(5), 392-402. Crossref

- Feurer, R., \& Chaharbaghi, K. (1994). Defining competitiveness. Management Decision, 32(2), 49-58. $\underline{\text { Crossref }}$

- Frankenberger, K., Weiblen, T., \& Gassmann, O. (2013). Network Configuration, Customer Centricity, and Performance of Open Business Models" A Solution Provider Perspective. Industrial marketing Management, 42, 671-682. Crossref

- Hair, J. F., Black, W. C., Babin, B. J., \& Anderson, R. E. (2010). Multivariate data analysis (7 ed.). New York: A Global Perspective.

- Harrison, B. (1994). Lean and Mean: The Changing Landscape of Corporate Power in the Age of Flexibility. New York: Basic Book.

- Harrison, B., Kelley, M. R., \& Grant, J. (1996). Innovative firm behavior and local milieu: exploring the intersection of agglomeration, firm effects, and technological change. Economic Geography, 72(3), 233-258. Crossref

- Holcombe, R. G. (2012). The Rise and Fall of Agglomeration Economies. In D. E. Andersson (Ed.), The Spatial Market Process (Vol. 16, pp. 211-232): Emerald Group Publishing Limited. Crossref

- Homburg, C., Grozdanovic, M., \& Klarmann, M. (2007). Responsiveness to customers and competitors: The role of affective and cognitive organizational systems. Journal of Marketing, 71(3), 18-38. Crossref

- Hulland, J., Wade, M. R., \& Antia, K. D. (2007). The impact of capabilities and prior investments on online channel commitment and performance. Journal of Management Information System, 23(4), 109-142. Crossref

- Hultman, C. M., \& Shaw, E. (2003). The Interface between Transactional and Relational Orientation in Small Service Firm's Marketing Behaviour: A Study of Scottish and Swedish Small Firms in the Service Sector. Journal of Marketing Theory and Practice, 11(1), 36-51. $\underline{\text { Crossref }}$

- Hunt, S. D. (1997). Competing through relationships: Grounding relationship marketing in resource-advantage theory. Journal of Marketing Management, 13(5), 431-445. Crossref

- Ireland, R. D., \& Bruce, R. (2000). Logistics and inter-departemental integration. Supply Chain Management Review(September/October), 80-88.

- Jaworski, B., \& Kohli, A. K. (1993). Marketing orientation: Antecendents and consequences. Journal of Marketing, 57(July), 53-70. $\underline{\text { Crossref }}$

- Johnson, M. W., Christensen, C. M., \& Kagermann, H. (2008). Reinventing your business model. Harvard Business Review, 86(12), 50-59. 
- Krugman, P. (1991). Geography and Trade. Cambridge, MA: MIT Press.

- Lai, W.-H., \& Woodside, A. G. (2015). Heuristics-in-use in industrial interfirm-collaborating clusters. Journal of Business \& Industrial Marketing, 30(3/4), 394-404. Crossref

- Lehrer, M., Ordanini, A., DeFillippi, R., \& Miozzo, M. (2012). Challenging the ortodoxy of value co-creation theory: A contigent view of co-production in design-intensive business services. European Management Journal, 30(6), 499-509. Crossref

- Luo, X. (2010). Product competitiveness and beating analyst earnings target. Journal of the Academy of Marketing Science, 38(3), 253-264. Crossref

- Marco-Lajara, B., Claver-Cortes, E., \& Ubeda-Gracia, M. (2014). Business agglomeration in tourist districts and hotel performance. International Journal of Contemporary Hospitality Management, 26(8), 1312-1340. Crossref

- Mare, D. C., \& Graham, D. J. (2013). Agglomeration elasticities and frm heterogeneity. Journal of Urban Economics, 75, 44-56. $\underline{\text { Crossref }}$

- Marques, C. S., \& Ferreira, J. (2009). SME innovation capacity, competitive advantage and performance in a Traditional Industrial Regional of Portugal. Journal of Technology Management \& Innovation, 4(4), 53-68. $\underline{\text { Crossref }}$

- Moon, H. C., \& Perry, N. S. (1995). Competitiveness of product, firm, industry and nation in a global business. Competitiveness review: An International Business Journal, 5(1), 37-43. Crossref

- Morgan, N. A. (2012). Marketing and business performance. Journal of the Academy of Marketing Science, 40, 102-119. Crossref

- Morgan, R. M., \& Hunt, S. D. (1994). The commitment-trust theory of relationship marketing. Journal of Marketing, 58(3), 20-38. Crossref

- Morrison, A., \& Teixeira, R. (2004). Small business performance: a tourism sector focus. Journal of Smal Business and Enterprise Development, 11(2), 166-173. Crossref

- Narver, J. C., \& Slater, S. F. (1990). The effect of a market orientation on business profitability. Journal of Marketing, 54(4), 20-35. Crossref

- Nwokah, N. G. (2009). Customer-Focus, Competitor-Focus, and Marketing Performance. Measuring Business Excellence, 13(3), 20-28. Crossref

- Nwokah, N. G., \& Maclayton, D. W. (2006). Customer-focus and business performance: the study of food and beverages organizations in Nigeria. Measuring Business Excellence, 10(4), 65-76. $\underline{\text { Crossref }}$

- Palmatier, R. W. (2008). Relationship Marketing. Massachusetts, USA: Marketing Science Institute.

- Palmatier, R. W., Scheer, L. K., Evans, K. R., \& Arnold, T. J. (2008). Achieving Relationship Marketing Effectiveness in Business-to-Business Exchanges. Journal of Academic Marketing Science, 36, 174-190. Crossref

- Prahalad, C. K., \& Ramaswamy, V. (2004). Co-creation experiences: The next practice in value creation. Journal of Interactive Marketing, 18(3), 5-14. Crossref

- Ravald, A., \& Gronroos, C. (1996). The Value Concept and Relationship Marketing. European Journal of Marketing, 30(2), 19-30. Crossref

- Ross, B. (2009). Ten tips to winning at consumer centricity: For retailers and manufacturers. Journal of Consumer Marketing, 26(6), 450-454. Crossref

- Sabath, R., \& Fontanella, J. (2002). The unfulfilled promise of supply chain collaboration. Supply Chain Management Review(July/August), 24-29.

- Scase, R., \& Goffee, R. (1984). The Real World of the Small Business Owner. London: Routedge.

- Schilling, M. A., \& Phelps, C. C. (2007). Interfirm collaboration networks: The impact of large-scale network structure on firm innovation. Management Science, 53(7), 113-1126. Crossref

- Scott, A. (2006). Entrepreneurship, innovation and industrial development: Geography and the creative field revisited. Small Business Economics, 26(1), 1-24. Crossref

- Sigalas, C., Pekka Economou, V., \& Georgopoulis, N. B. (2013). Developing a measure of competitive advantage. Journal of Strategic and Management, 6(4), 320-342. Crossref

- Stahl, K. (1982). Differentiated products, consumer search, and locational oligopoly. The Journal of Industrial Economics, 31(1/2), 97-113. $\underline{\text { Crossref }}$

- Su, P., Liu, S., \& Lin, J. (2017). Agglomeration effect and the "dual-format" e-marketplace pricing scheme. Journal of Modelling in Management, 12(1), 19-35. Crossref 
- Sugiyarti, G., \& Ardyan, E. (2017). Market sensing capability and product innovation advantages in emerging markets: The case of market entry quality and marketing performance of Batik Industry in Indonesia. DLSU Business and Economics Review, 27(1), 175-189.

- Swass, V. (2010). Co-creation: Toward a taxonomy and an integrated research perspective. International Journal of Electronic Commerce, 15(1), 11-48. Crossref

- Tidd, J., Bessant, J. R., \& Pavitt, K. (2005). Managing innovation: Integrating technological, market and organizational change (3 ed.). USA: John Wiley \& Son Inc.

- Tse, A. C. B., Sin, L. Y. M., Yau, O. C. B., Lee, J. S. Y., \& Chow, R. (2004). A Firm's Role in the Marketplace and the RElative Importaance of Market Orientation and Relationship Marketing Orientation. European Journal of Marketing, 38(9/10), 1158-1172. Crossref

- Vieira, A. L. (2009). Business to Business Relationship Quality. Portuguese Journal of Management Studies, XIV(3), 197-215.

- Wang, G., Dou, W., Zhu, W., \& Zhou, N. (2015). The effects of firm capabilities on external collaboration and performance: The moderating role of market turbulence. Journal of Business Research, 68(9), 1928-1936. Crossref

- Wang, Z. W., \& Wang, N. (2012). Knowledge sharing, innovation and firm performance. Expert System with Application, 39(10), 3899-8908. Crossref

- Wei, Y., Samiee, S., \& Lee, R. P. (2014). The influence of organic organization cultures, market responsiveness, and product strategy on firm performance in an emerging market. Journal of the Academy of Marketing Science, 42(1), 49-70. Crossref

- Wiese, N. (2017). The effects of institutional quality and market potential on the agglomeration of fast food franchises in Central America. Management Research: Journal of the Iberoamerican Academy of Management, 15(3), 268-291. Crossref

- Zhang, X., \& Chen, R. (2008). Examining the mechanism of the value co-creation with customers. International Journal of Production Economics, 116(2), 242-250. Crossref

- Zhao, Y., Zhou, W., Husig, S., \& Vanhaverbeke, W. (2010). Environment, network interactions and innovation performance of industrial clusters Evidences from Germany, The Netherlands and China. Journal of Science and Technology Policy in China, 1(3), 2010. $\underline{\text { Crossref }}$ 